\title{
Strategi Evaluasi Formatif Sebagai Peningkatan Keterampilan Menari
}

\author{
Dinny Devi Triana \\ Universitas Negeri Jakarta \\ Jl. Rawamngun Muka Jakarta Timur 13220 \\ dini_devi@yahoo.com
}

\begin{abstract}
This study aims to improve her dancing skills through assessment strategies as a formative evaluation, thereby increasing the dancing skills of students and faculty assist in conducting the assessment is not only done in the midterm and final exams. This is necessary due to the characteristics of different dance practice learning the theory that is both classical learning. Based on these objectives, then the classroom action research (PTK) with design Clasroom Action Research developed Kemmish and Tagart, where action and observation conducted simultaneously. Results from the study showed a significant increase, where the percentage increased from a pre-condition to cycle 1 was $17 \%$, while from the end of the second cycle of $4.7 \%$. Thus the assessment strategy as one of the formative evaluation will be to encourage students to improve the ability to dance, because at this event will take place reflection and does not cause psychological distress as well as when testing skills.
\end{abstract}

Keywords: Assessment strategies, formative evaluation, dancing skills, learningdance practice

\begin{abstract}
ABSTRAK
Penelitian ini bertujuan untuk meningkatkan kemampuan keterampilan menari melalui strategi penilaian sebagai evaluasi formatif, sehingga akan meningkatkan keterampilan menari peserta didik dan membantu tenaga pengajar dalam melakukan penilaian yang tidak hanya dilakukan dalam ujian tengah semester dan ujian akhir semester. Hal ini diperlukan karena karakteristik pembelajaran praktik tari berbeda dengan pembelajaran teori yang bersifat klasikal.Berdasarkan tujuan tersebut, maka dilakukan penelitian tindakan kelas (PTK) dengan desain Clasroom Action Research yang dikembangkan Kemis dan Tagart, di mana tindakan dan observasi dilakukan bersamaan. Hasil dari penelitian menunjukkan adanya peningkatan yang signifikan, di mana pada prosentasi kenaikan dari pra kondisi ke siklus 1 sebesar $17 \%$, sedangkan dari akhir siklus 2 sebesar 4,7\%. Dengan demikian strategi penilaian sebagai salah satu evaluasi formatif akan dapat mendorong peserta didik dalam meningkatkan kemampuan menari, karena pada kegiatan ini akan terjadi refleksi dan tidak menimbulkan tekanan psikologis seperti halnya apabila dilakukan tes keterampilan.
\end{abstract}

Kata kunci: Strategi penelitian, evaluasi formatif, keterampilan menari, pembelajaran praktek tari. 


\section{PENDAHULUAN}

Pembelajaran praktik tari memiliki karakteristik yang berbeda dengan pembelajaran lainnya, untuk itu diperlukan tenaga pengajar yang memiliki komampuan menari dengan baik, kompetensi pedagogik yang mampu mengajarkan tari dengan berbagai metode termasuk sistem evaluasinya.Namun demikian disamping tenaga pengajar, pembelajaran praktik tari juga harus memiliki sarana prasarana yang memadai, serta harus memperhitungkan jumlah peserta didik agar terjadi keseimbangan antara tenaga pengajar dengan peserta didiknya.

Kompetensi tenaga pengajar di bidang keterampilan tari biasanya sudah sesuai dengan repertoar yang dikuasai, namun kompetensi pedagogik masih menggunakan metode konvensional yaitu hanya dengan metode demonstrasi, latihan dan penugasan.Demikian pula pada sistem evaluasi yang digunakan, sehingga evaluasi yang dilakukan tidak mendorong peserta didik untuk meningkatkan keterampilan menari sesuai dengan tujuan pembelajaran praktik tari.Bahkan seringkali tenaga pengajar tidak dapat mendiagnosis kemampuan menari peserta didik secara individual, karena rasio antara tenaga pengajar dan peserta didik sudah tidak ideal lagi.Karena itu dibutuhkan strategi penilaian yang memungkinkan tenaga pengajar dapat melakukan evaluasi formatif.

Strategi penilaian yaitu cara atau suatu tindakan yang ditetapkan dalam pengambilan keputusan dengan menggunakan informasi melalui pengukuran. Strategi penilaian digunakan sebagai garis arah atau cara untuk bertindak, dan dibuat untuk mencapai tujuan yang telah ditetapkan dengan memperhitungkan kekuatan serta kelemahannya. Dengan demikian Strategi penilaian lebih banyak berhubungan dengan teknik, cara melakukan penilaian dalam suatu pembelajaran agar dapat mendiagnosis kekuatan dan kelemahan peserta didik.

Penilaian adalah suatu proses untuk mengambil keputusan dengan menggunakan informasi yang diperoleh melalui pengukuran, baik menggunakan instrumen tes maupun non-tes. Demikian pula Aiken (1988: 354) mengatakan bahwa penilaian adalah taksiran atau penaksiran tentang sifat-sifat seseorang, proses penilaiannya mencakup pengamatan, wawancara, rentang skala daftar chek list, kuesioner, proyektif, dan tes psikologi. Penilaian dalam konteks pendidikan adalah suatu proses untuk memperoleh keterangan dan dokumen tentang perkembangan belajar siswa. Senada dengan Popham (1995: 3) bahwa penilaian dalam pendidikan adalah suatu usaha formal untuk menentukan status siswa berkenaan dengan variabel-variabel bidang pendidikan yang menjadi perhatian, sedangkan menurut Cangelosi dalam Lilian (1995: 21), penilaian yaitu keputusan tentang nilai dan penilaian dipengaruhi oleh unsur pengukuran.

Berdasarkan definisi tersebut maka penilaian dapat dikatakan sebagai suatu proses pengumpulan data yang dilakukan secara sistematis, kemudian dianalisis dan diinterpretasikan untuk mendapatkan keputusan atau informasi tentang kedudukan serta perkembangan belajar siswa yang mencakup sifat-sifatnya. Proses pengambilan data dalam penilaian tersebut dapat dilakukan melalui berbagai teknik tergantung pada tujuan yang akan dinilai ranah kognitif, afektif atau psikomotor.

Pada pembelajarn praktik tari yang kegiatannya lebih mengutamakan psiko- 
motor diperlukan evaluasi untuk memperbaiki serta meningkatkan hasil belajar dengan menggunakan penilaian kinerja. Menurut Nyoman (2009) dalam Dinny (2012: 34) ada tiga cara penilaian kinerja, yaitu: (1) holistic scoring, yaitu pemberian skor berdasarkan impresi penilai secara umum terhadap kualitas performansi; (2) analytic scoring, yaitu pemberian skor terhadap aspek-aspek yang berkontribusi terhadap suatu performansi; dan (3) primary traits scoring, yaitu pemberian skor berdasarkan beberapa unsur dominan dari suatu performansi, di mana kriteria penilaian adalah produknya, sedangkan proses mencapai kriteria tersebut dipantau dengan menggunakan ceklis evaluasi diri.

Kelemahan penilaian kinerja dilakukan karena membutuhkan tingkat realisme yang tinggi dan pengukuran yang cermat, sehingga penilaian kinerja ini membutuhkan waktu. Unsur subjektivitas seringkali terjadi pada penilaian kinerja, untuk itu dibutuhkan beberapa penilai atau pemberi tanggapan yang lebih dari satu orang, agar hasil penilaian konsistens dan objektif. Penilaian pembelajaran praktik tari, tidak hanya dilakukan tenaga pengajar, tetapi juga melalui penilaian diri dan penilaian teman sejawat, kemudian disilangkan untuk mendapatkan hasil penilaian yang dapat dipertanggungjawabkan.

Evaluasi pada pembelajaran dilaksanakan tidak hanya pada akhir pembelajaran, tetapi juga selama pembelajaran berlangsung. Dalam menentukan tujuan dan fungsi, evaluasi pembelajaran tersebut sangat diperlukan, untuk membantu tenaga pengajar dalam menentukan sistem evaluasi yang harus digunakan.Evaluation dalam buku Essentials of Education karangan Wand dan Brown dalam Mulyana, dkk (2004: 2) dikatakan bahwa: Evaluation refer to the act or proses to determining the value of something the value of something. Menurutnya, evaluasi adalah suatu tindakan atau suatu proses untuk menentukan nilai dari sesuatu. Sesuai dengan pendapat tersebut maka evaluasi hasil belajar dapat diartikan sebagai suatu tindakan atau suatu proses untuk menentukan nilai keberhasilan belajar setelah ia mengalami proses belajar selama satu periode tertentu.

Tujuan evaluasi dalam pembelajaran tari terkait dengan berbagai aspek, baik pengetahuan, sikap, dan keterampilan.Oleh karena itu diperlukan sistem evaluasi yang seimbang antara aspek tersebut untuk mencapai tujuan antara lain: 1) mengetahuai tingkat kemampuan siswa dalam aspek pengetahuan, khususnya yang bersifat konsepsi dan apresiasi, 2) mengembangkan minat dan bakat siswa dalam meningkatkan keterampilan menari, 3) memperbaiki sikap atau perilaku siswa kaitannya dengan etika dan memperhatikan norma estetika.

Berdasarkan tujuan evaluasi tersebut, maka hasil akhir yang ingin dicapai dari pembelajaran tari yaitu pengetahuan,sikap, dan skill (keterampilan) menari. Keterampilan adalah hasil belajar pada ranah psikomotorik, yang terbentuk menyerupai hasil belajar kognitif. Keterampilan berasal dari kata terampil yang artinya cakap dalam menyelesaikan tugas. Keterampilan berarti kecekatan, kacakapan dalam menyelesaikan tugas (Kamus Besar Bahasa Indonesia on line). Keterampilan adalah kecakapan dan potensi yang dimiliki oleh seseorang untuk menguasai suatu keahlian.Keterampilan tersebut merupakan suatu hasil latihan yang digunakan untuk melakukan sesuatu. Dengan demikian keterampilan menari dapat dicapai atau ditingkatkan melalui latihan, dan salah satunya adalah melalukan evaluasi formatif secara berkesinambungan. Hal ini dapat dicapai melalui pembelajaran tari yang terencana, tersusun, dan terukur. 
Belajar menurut Winkel (1997:50) adalah suatu aktivitas mental atau psikis yang berlangsung dalam suatu interaksi aktif dengan lingkungan yang menghasilkan perubahan-perubahan dalam pengetahuan, pemahaman, pengalaman, ketrampilan, dan nilai sikap.Adapun belajar menurut Suryabarata (1998: 232) merupakan hal yang penting bagi setiap manusia, karena belajar sangat membantu manusia untuk menyesuaikan diri dalam perkembangan hidupnya. Berdasarkan teori belajar tersebut, dapat disimpulkan terdapat hal-hal pokok dalam belajar, yaitu belajar akan membawa perubahan (dalam arti behavior changes yaitu perubahan tingkah laku, aktual maupun potensial). Perubahan itu pada pokoknya adalah didapatkannya kecakapan baru, dan terjadi karena usaha (dengan sengaja).Demikian pula dalam pembelajaran praktik tari, dimana adanya perubahan potensi berupa kecakapan atau keterampilan terjadi karena adanya usaha tertentu dengan memperhatikan aspek yang menjadi esensi dalam tari.

Esensi dari tari adalah gerak, tetapi struktur gerak dalam tari itu sendiri meliputi beberapa aspek.Laban dalam Hutchinson (1989:12) mendeskripsikan gerak menjadi beberapa bagian yaitu the body (bagian spesifik dari gerak, misalnya gerak bagian kepala, kaki, tangan, badan), space (ruang gerak, misalnya level, jarak/ rentangan atau tingkatan gerak), time (waktu, misalnyai durasi gerak) dan dynamics (Kualitas atau tekstur gerak, misalnya gerak yang kuat, lemah, elastis, aksentuasi, penekanan).Untuk itu dapat disimpulkan bahwa gerak dalam tari terdiri dari ruang, tenaga dan waktu.

Thraves dan Williamson (1993: 1) menyatakan bahwa "These movement, necessary for living can be extended by reguler practice into another dimension. They can become a dance". Pada dasarnya tari berasal dari gerak yang dimiliki oleh manusia yang dapat dikembangkan menjadi suatu tarian. Sesuai dengan pendapat tersebut, John Martin (1986: 22-23) menyatakan bahwa materi dasar dari tari adalah gerak.

Lebih lanjut dijelaskan adanya ruang dalam tari. Ruang diperlukan manusia untuk melakukan gerak tubuhnya, sehingga semua gerak yang diungkapkan oleh manusia terbentuk sebagai akibat perpindahan tubuh atau anggota tubuh manusia dari suatu ruang ke ruang yang lain (Slater, 1993: 3-5). Laban (1992: 85) sendiri membagi ruang menjadi ruang pribadi dan ruang umum, ruang pribadi adalah ruang yang langsung bersentuhan dengan tubuh si penari, adapun batas imajinasinya adalah batas yang paling jauh yang dapat dijangkau oleh tangan dan kakinya dalam keadaan di tempat, sedangkan ruang secara umum adalah ruangan di luar tubuh yang dapat dimasuki apabila terjadi gerakan perpindahan tempat asal ke tempat lain.

Selain ruang dibutuhkan tenaga untuk menghasilkan gerak. Gerak dalam tari akan terlihat intensitas dan kualitas estetisnya apabila tenaga tersebut dikeluarkan sesuai dengan cara bagaimana tenaga itu sendiri disalurkan untuk menghasilkan gerak. Menurut Smith tenagalah yang menjadi sumber (pangkal) penghasil gerak, dia akan terus berjalan dan berhenti, sehingga akan memberikan wujud penekanan dan pengendoran tenaga selama menari (Smith, 1985: 61). Laban (1992: 19) menegaskan, The driving force of movement is the energy developed by a process of combustion within the organs of the body. Hal ini berarti tenaga merupakan daya untuk dapat menghasil-kan gerak dari suatu proses pembakaran di dalam tubuh. Melalui tenaga tersebut, maka gerak yang diungkapkan mempunyai dinamika, sehingga gerak akan mempunyai isi atau jiwa. 
Tenaga akan terkait dengan ekspresi, sebab tenaga sebagai salah satu unsur gerak, merupakan daya penggerak dari dalam diri si penari dan berperan di dalam kualitas ekspresi yang menghasilkan suatu daya hidup atau greget dari sebuah tarian. Greget adalah istilah dalam tari Jawa yang artinya dorongan perasaan, desakan batin atau ekspresi jiwa seseorang dalam bentuk tari yang terkendali (Soedarsono, 1997:35). Martin (1989: 8) menyatakan, "phsycal movement is the normal first effect of mental or emotional eksperience. To some extent the actor works on this basis, if he is a good actor...". Artinya gerak fisik adalah efek normal pertama dari pengalaman mental atau emosional manusia. Dengan demikian ekspresi hal yang juga esensial dalam tari untuk memancarkan kekuatan serta pesan atau maksud yang ingin disampaikan dalam suatu bentuk tari, sehingga dapat dimengerti orang lain sebagai suatu komunikasi yang diungkapkan melalui gerak.

Iringan dan tari memegang peranan penting, tari dan iringan tidak dapat dipisahkan satu sama lain, karena keduanya berasal dari sumber yang sama yaitu dorongan atau naluri ritmis. Seperti yang diungkapkan Humphrey (1964: 132) bahwa pada dasarnya tari membutuhkan kehadiran musik sebagai pendampingnya. Keterikatan tari dengan musik dinyatakan Doubler dalam kutipan "sebagai dorongan dinamik susunan ritmisnya, di samping kualitas-kualitas melodik dan harmonisnya, musik adalah suatu yang terpenting dari semua partner tari" (Doubler dalam Kumorohadi, 1985: 156).Dari pernyataan tersebut Doubler menggarisbawahi unsur ritme sebagai dasar penggerak kerjasama antar tari dan musik (Dinny, 2012: 32).

Berdasarkan permalasahan-permasalahan yang telah dipaparkan, serta dengan tidak idealnya antara jumlah tenaga pengajar dan jumlah peserta didik dalam satu kelas pembelajaran, maka diperlukan strategi penilaian yang diterapkan pada evaluasi formatif. Fungsinya adalah untuk mengetahui kemajuan siswa selama pengajaran, sehingga dapat mengukur sampai sejauh mana suatu bagian pelajaran sudah dikuasai. Evaluasi formatif pada pembelajaran tari dibutuhkan agar tenaga pengajar mengetahui kemampuan keteram-pilan menari peserta didik dari waktu ke waktu secara berkelanjutan. Evaluasi yang dilakukan secara berkelanjutan tentu dapat membantu tenaga pengajar dalam men-diagnosis kekuatan dan kelemahan peserta didik di setiap bagian materi tari yang dipelajari.

\section{METODE}

Desain intervensi tindakan/rancangan siklus penelitian ini menggunakan model Kemmis dan Mc Taggart dalam Arikunto, pada dasarnya merupakan suatu siklus yang meliputi tahap-tahap: (a) perencanaan (planning), (b) tindakan (acting) dan observasi (observing), (c) refleksi (reflecting), dari terselesaikannya refleksi lalu dilanjutkan dengan perencanaan kembali (replanning), dan disusun sebuah modifikasi yang dituliskan dalam bentuk rangkaian tindakan dan pengamatan lagi, begitu seterusnya membentuk sebuah siklus (Arikunto, 2006: 93). Kemis \& Tagart (1999: 15). Dengan demikian, aktivitas dalam penelitian tindakan ini melalui tahapan dan siklus tertentu seperti terlihat pada gambar berikut:

Penelitian tindakan memerlukan hipotesis sebagai dasar menggambarkan dugaan sementara atas perubahan yang akan terjadi pada objek penelitian. Hipotesis tindakan pada penelitian ini dirumuskan sebagai berikut: strategi penilaian merupakan suatu cara atau teknik 


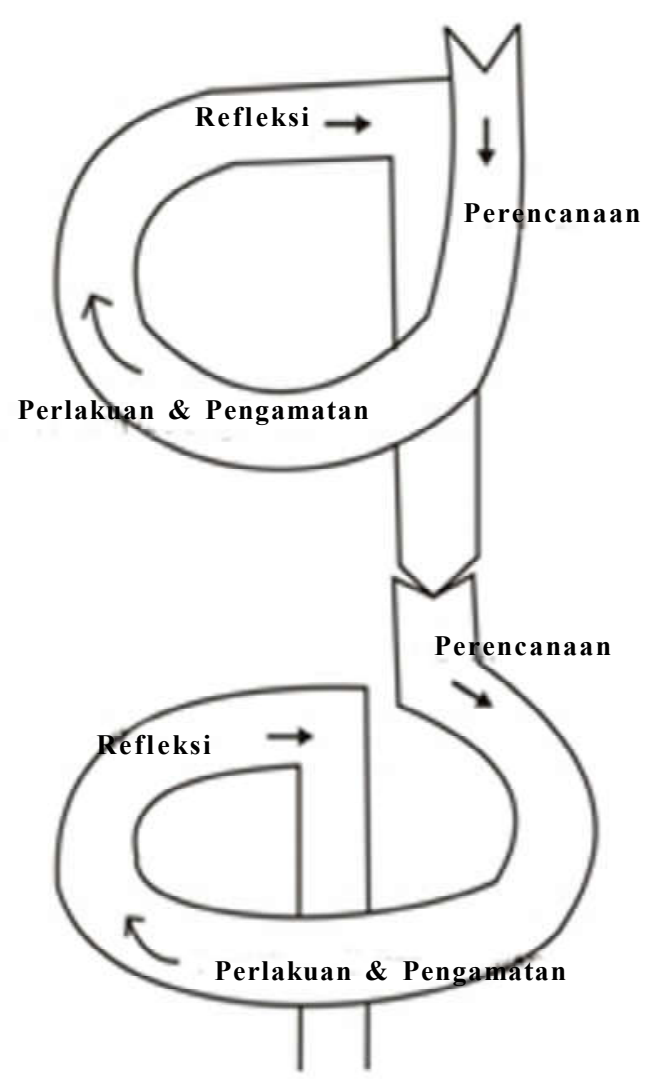

Gambar 1:

Model Spiral Penelitian Tindakan Menurut Kemmis dan Mc. Taggart (1999: 11)

dalam pengumpulan informasi untuk mengambil suatu keputusan yang diperoleh melalui pengukuran. Strategi penilaian ini dilakukan agar dapat mendiagnosis secara awal dan berkelanjutan untuk mengetahui kekuatan dan kelemahan peserta didik yang biasanya dilakukan pada kegiatan evaluasi formatif yaitu suatu proses untuk menentukan nilai keberhasilan belajar setelah mengalami proses belajar selama satu periode tertentu.

Keberhasilan belajar pada pembelajaran praktik tari umumnya menekankan pada keterampilan menari. Keterampilan menari mempunyai arti keberhasilan belajar dalam ranah psikomotorik untuk melakukan sesuatu dengan baik. Keterampilan akan dapat dicapai atau ditingkatkan dengan latihan tindakan secara berkesinambungan.
Oleh karenanya diperlukan penilaian yang berkelanjutan selama periode tertentu, sehingga dugaan terhadap tindakan pada penelitian dapat memberikan strategi penilaian sebagai evaluasi formatif untuk meningkatkan keterampilan menari, khususnya pada pembelajaran praktik tari.

Subjek dalam penelitian ini adalah peserta didik pada mata kuliah praktik Tari Betawi. Sementara partisipan dalam penelitian ini adalah peneliti sendiri sebagai planer leader, bersama kolaborator yaitu tenaga pengajar pengampu mata kuliah tari dasar Betawi yang memahami tentang tujuan pembelajaran pada Tari Betawi.

Peran peneliti dalam penelitian tindakan ini adalah sebagai pemimpin perencanaan (planner leader) yang menentukan waktu penelitian, menentukan objek penelitian, mencari sumber data. Selanjutnya melakukan pengamatan terhadap pembelajaran Tari Betawi khususnya pada penilaian kelas dan kemampuan membuat perencanaan tindakan yang didiskusikan dengan pengajar pengampu mata kuliah sebagai kolaborator. Selama proses penelitian, peneliti dan kolaborator melakukan pengamatan, kemudian hasil dari pengamatan tersebut dievaluasi secara kolaboratif. Hasil pengamatan dan refleksi tindakan yang telah dilakukan dapat digunakan sebagai bahan analisis data dan perencanaan untuk siklus selanjutnya.

Tahapan intervensi dilakukan, dengan didahului observasi. Hal ini bertujuan untuk mengetahui secara detail mengenai kondisi kelas dan subjek yang akan diteliti. Hasil dari kegiatan ini akan digunakan untuk berbagai hal terkait dengan implementasi penelitian tindakan kelas dan menentukan indikator keberhasilan.

Indikator keberhasilan dalam penelitian ini adalah apabila terjadi peningkatan keterampilan menari pada pembelajaran 
praktik Tari Betawi, baik yang terefleksi dalam data pemantau tindakan maupun berdasarkan data hasil penelitian.Peneliti dan kolaborator menyepakati bahwa penelitian ini dapat dikatakan berhasil apabila terjadi peningkatan keterampilan menari tari Betawi yang diperoleh setelah dilakukan tindakan yaitu berupa pemberian penilaian dengan berbagai strategi yang sudah dirancang sebelumnya.

Hal ini telah disepakati dengan mempertimbangkan bahwa setiap peserta didik memiliki keterampilan dasar tari yang berbeda. Peningkatan keterampilan menari yang diharapkan bukan hanya berupa konsep pemahaman gerak tari, tetapi juga peningkatan penguasaan tari yang akan dipelajari pada semester berikutnya. Pada data pemantau tindakan, dinyatakan berhasil apabila terjadi perubahan-perubahan keterampilan menari peserta didik saat diberikan berbagai strategi penilaian sebagai evaluasi formatif yang dapat mendiagnosis kekuatan dan kelemahan peserta didik.

Data pemantauan tindakan (action) merupakan data yang digunakan untuk mengontrol kesesuaian pelaksanaan tindakan dengan rencana, yaitu observasi dengan bantuan kamera. Sementara data penelitian (research) adalah data tentang variabel penelitian, yakni indikator keterampilan menari dalam pembelajaran praktik Tari Betawi. Data ini digunakan untuk keperluan analisis data penelitian sehingga diperoleh gambaran peningkatan keterampilan menari.

Teknik yang digunakan dalam menjaring data tentang pemantauan tindakan (action) adalah berbentuk catatan lapangan, catatan wawancara dan dokumentasi. Catatan lapangan dilakukan oleh kolaborator dan dilakukan secara langsung dibantu dengan menggunakan kamera sebagai dokumentasi. Pada teknik pengumpulan data menggunakan instrumen sejumlah tugas yang mengukur keterampilan menari peserta didik. Teknik pengumpulan data yang digunakan untuk menjaring data penelitian menggunakan pengamatan antar teman sejawat, dan tenaga pengajar untuk mengetahui peningkatan keterampilan menari peserta didik. Teknik observasi yang digunakan untuk observasi terstruktur (structured or controlled observation), yaitu observasi yang direncanakan dan ter-kontrol. Pada observasi terstruktur, penga-mat mengisi daftar isian yang tersusun di dalam aspekaspek yang perlu diperhatikan pada waktu pengamatan dilakukan.

Analisis data menggunakan analisis secara kualitatif sebagaimana yang dikemukakan yakni melalui tahapan: (1) reduksi data, (2) uraian data, dan (3) penarikan kesimpulan. Analisis data, diperkuat dengan melakukan penghitungan rata-rata dan prosentase terhadap hasil pengukuran keterampilan menari peserta didik, sehingga data dilengkapi dengan adanya matrik atau grafik.

\section{HASIL DAN PEMBAHASAN}

Pada pengambilan data pre test untuk mengetahui kondisi awal instrumen yang diberikan adalah: 1) demosntrasikan gerak Betawi yang diketahui, 2) demonstrasikan Tari Betawi yang dikuasai, 3) demonstrasikan gerak tari asal daerah yang dikuasai, dan 4) menjelaskan pengalaman belajar tari di sanggar/sekolah. Dari ke-4 butir instrumen tersebut diharapkan akan memperoleh data tentang kemampuan kognitif, afektif, dan psikomotorik peserta didik dalam kemam-puan menari Tari Betawi.

Jika dinyatakan dalam bentuk grafik diperoleh data sebagai berikut: 


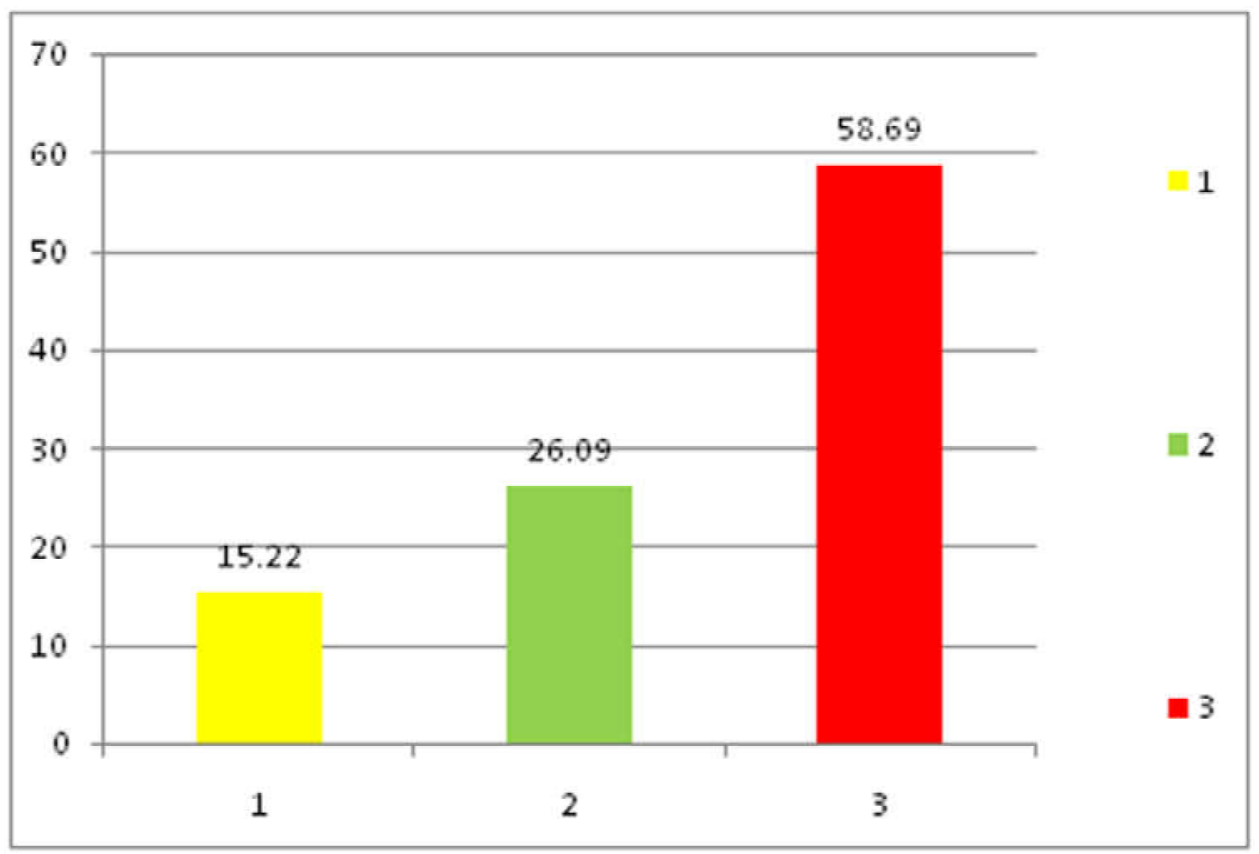

Diagram 1:

Kondisi Awal (Diolah oleh: Dinny Devi T)

Berdasarkan hasil tersebut diketahui nilai baik hanya 7 orang dari total jumlah peserta didik atau $15 \%$, nilai cukup hanya 12 orang dari total jumlah peserta didik atau $26,09 \%$, dan nilai kurang 27 orang atau $58,69 \%$, dan nilai rata-rata dari data tersebut sebesar 59,60. Dengan demikian presentasi kemampuan yang di bawah standar berjumlah 39 orang atau $84.78 \%$.

Rancangan penelitian terbagi menjadi 2 siklus yang dapat digambarkan sebagai berikut:

\section{Hasil Siklus 1}

Hasil refleksi kemudian dikorelasikan dengan penilaian pengajar, Hal ini dilakukan untuk menguji silang hasil atau cros check hasil refleksi yang dilakukan antar kelompok/teman sejawat dengan hasil tes pengamatan yang diberikan tenaga pengajar. Hasilnya menunjukkan nilai rata-rata yang diperoleh 78.18 yang artinya masih di bawah 80 yang dijadikan batas ketuntasan belajar.
Berdasarkan perolehan nilai tersebut maka dilanjutkan siklus 2 untuk capaian nilai rata-rata 80 .Siklus berikutnya dilakukan melalui media audio visual sebagai media pembelajaran dan perbandingan atas kemampuan yang telah dimiliki pada siklus 1. Berikut perbandingan antara pra kondisi atau sebelum diberi perlakuan dan setelah diberi perlakuan pada siklus 1 :

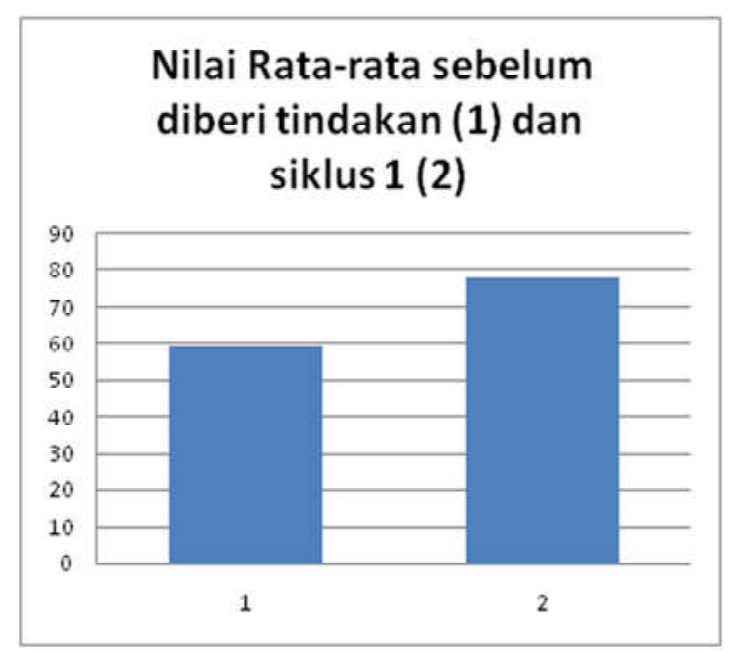

Diagram 2:

Peningkatan Kemampuan Kondisi Awal (1), Siklus 1 (2), (Diolah oleh: Dinny Devi T) 


\begin{tabular}{|c|c|}
\hline SIKLUS 1 & SIKLUS 2 \\
\hline $\begin{array}{l}\text { Perencanaan; } \\
\text { - Penyusunan RPKPS tari dasar } \\
\text { Betawi untuk materi ragam gerak } \\
\text { tari dasar Betawi dan Tari Cokek } \\
\text { Sirih Kuning bersama kolabolator } \\
\text { dan timpengajar pengampu mata } \\
\text { kuliah } \\
\text { - Penyusunan instrumen evaluasi } \\
\text { formatif } \\
\text { - Penyusunan lembar pengamatan } \\
3 W+1 H \text { (wiraga, wirama, wirasa, } \\
\text { hafalan) }\end{array}$ & $\begin{array}{l}\text { Perencanaan; } \\
\text { - Pery usunan materi ragam gerak } \\
\text { dasar Tari Betawi dan Tari Cokek } \\
\text { Sirih Kuring yang menekankan } \\
\text { kepada wirasa. } \\
\text { - Melengkapi materi dengan media } \\
\text { VCD pembelajaran tari. } \\
\text { - Memberikan tugas terst ruktur } \\
\text { berupa mempelajari tari Betawi } \\
\text { lainrya di luar perkuliahan agar } \\
\text { peserta didik memiliki } \\
\text { perbendaharaan tari Betawi yang } \\
\text { lebih banyak danmempelajari tari } \\
\text { Betawi dengan gerak-gerak yang } \\
\text { lebih kompleks. }\end{array}$ \\
\hline $\begin{array}{l}\text { Tindakan dan Observasi: } \\
\text { - Peserta didik diberikan teknik } \\
\text { ragam gerak tari dasar Betawi yang } \\
\text { merupakan dasar-dasar gerak dari } \\
\text { tari Topeng. } \\
\text { - Evaluasi dilakukan per kelompok, } \\
\text { masing-masing kelompok berjumlah } \\
5 \text {-6 orang melalui media audio } \\
\text { visual } \\
\text { - Kolabolator, timpengajar bersama- } \\
\text { sama memberikan masukan dergan } \\
\text { memperturiukan hasil rekaman } \\
\text { audio visual. } \\
\text { - Peserta didik memberikan penilaian } \\
\text { antar kel ompok dalam bentuk } \\
\text { laporan } \\
\text { Pengajar memberikan penilaian } \\
\text { individupada peserta didik dalam } \\
\text { memperagakan tari ragam gerak } \\
\text { dasar Betawi dan Tari Cokek Sirih } \\
\text { Kuning }\end{array}$ & $\begin{array}{l}\text { Tindakan dan Observasi: } \\
\text { - Pese rta didik mengapresiasi melalui } \\
\text { VCD pembelajaran tari Betawi } \\
\text { materi ragam gerak tari Betawi dan } \\
\text { cokek Sirih Kuning. } \\
\text { - Pese rta didik memberik an perilaian } \\
\text { terhadap materi tari yang diparesiasi } \\
\text { dan membanding kannya dengan } \\
\text { keterampilan yang dimiliki } \\
\text { - Kolabolator, timpengajar be rsama- } \\
\text { sama memberikan masukan dengan } \\
\text { memperagakan kembali tekhnik- } \\
\text { tekhnik gerak yarg dianggap masih } \\
\text { sulit dilakukanpeserta didik. } \\
\text { - Pese rta didik memberikan cata tan } \\
\text { atas kekurangannya setelah } \\
\text { mempelajari ragam gerak dasar tari } \\
\text { Betawi dan Tari Cokek Sirih Kuring } \\
\text { dan setelahmembandingkandengan } \\
\text { tayanganVCD pembelajaran tari. } \\
\text { - Kolabolator dan timpengajar } \\
\text { memberikan penilaian pada eval uasi } \\
\text { individu yaitu peserta didik } \\
\text { memperagakan tari ragam gerak }\end{array}$ \\
\hline
\end{tabular}



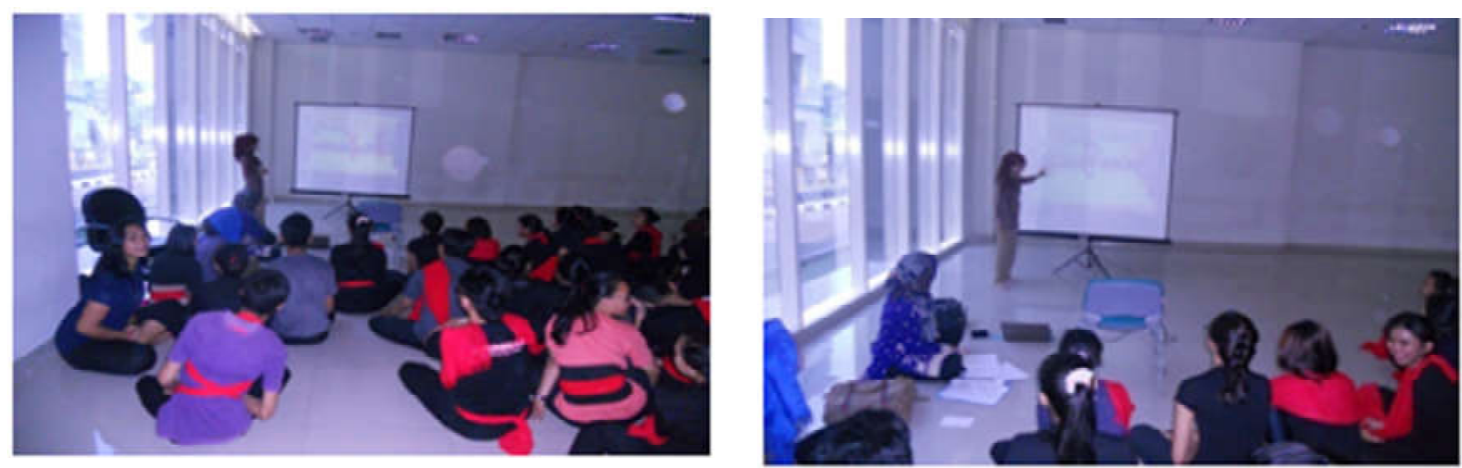

Gambar 2:

Proses tindakan dan observasi

(Dokumentasi: Dinny Devi T, 2014)

Berdasarkan grafik dan hasil refleksi pada siklus 1 menunjukkan masih banyak kekurangan penguasaan keterampilan tari ragam gerak dasar dan Tari Cokek Sirih Kuning terutama penguasaan pada wirasa. Pada siklus 2 dilanjutkan dengan perlakuan kepada wirasa agar dapat memenuhi tujuan untuk mengetahui batas keterampilan minimal yaitu mencapai nilai 80 .

\section{Hasil Siklus 2}

Berdasarkan hasil refleksi siklus 2 menunjukkan adanya peningkatan, di mana pada pra kondisi hanya memiliki nilai ratarata 58,53, siklus 1 memiliki nilai rata-rata 75,53, dan siklus 3 memiliki nilai rata-rata 80,19 . Prosentasi kenaikan dari pra kondisi ke siklus 1 sebesar $17 \%$, sedangkan dari siklus 2 ke siklus 3 sebesar $4,7 \%$.

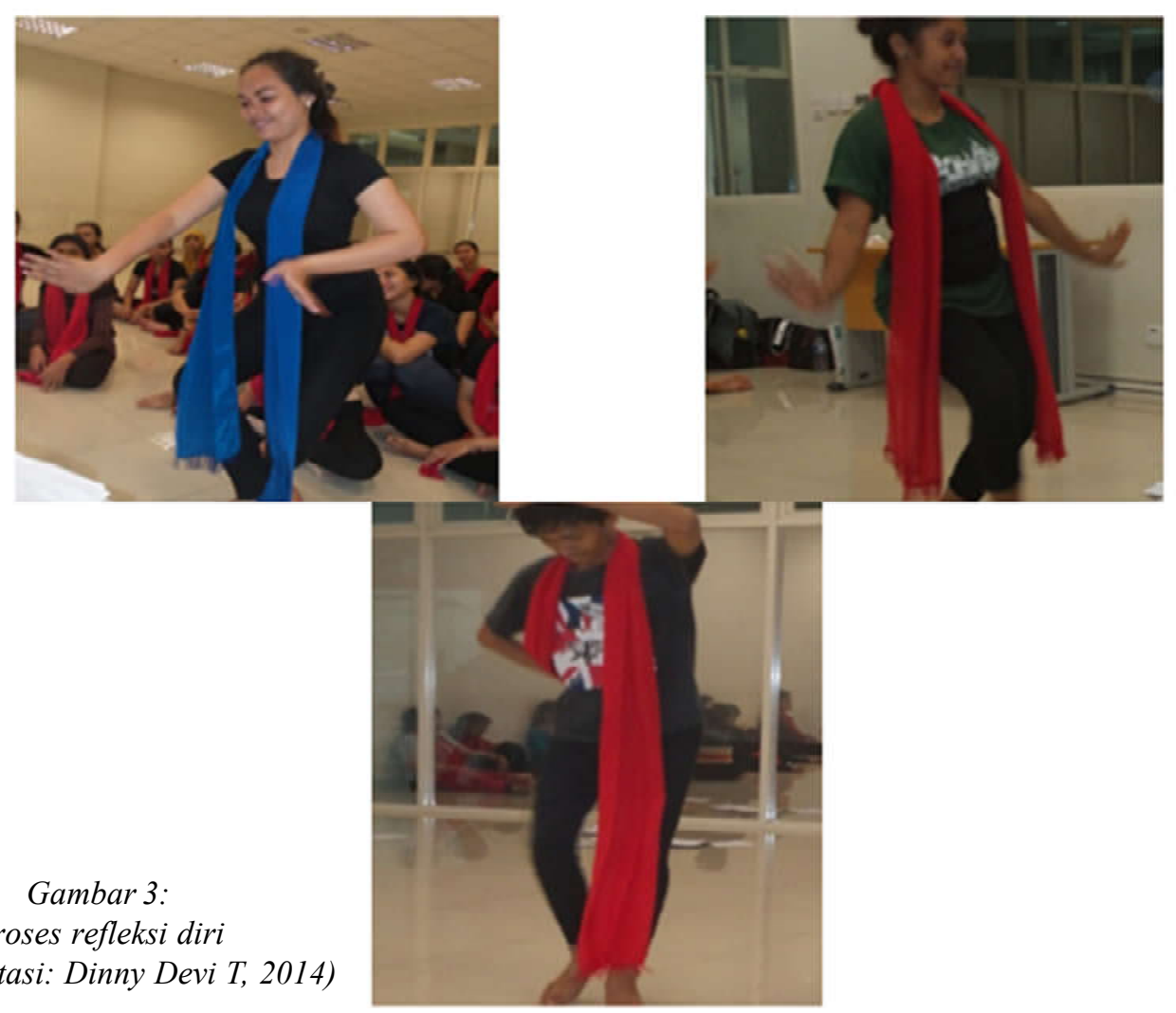

(Dokumentasi: Dinny Devi T, 2014) 


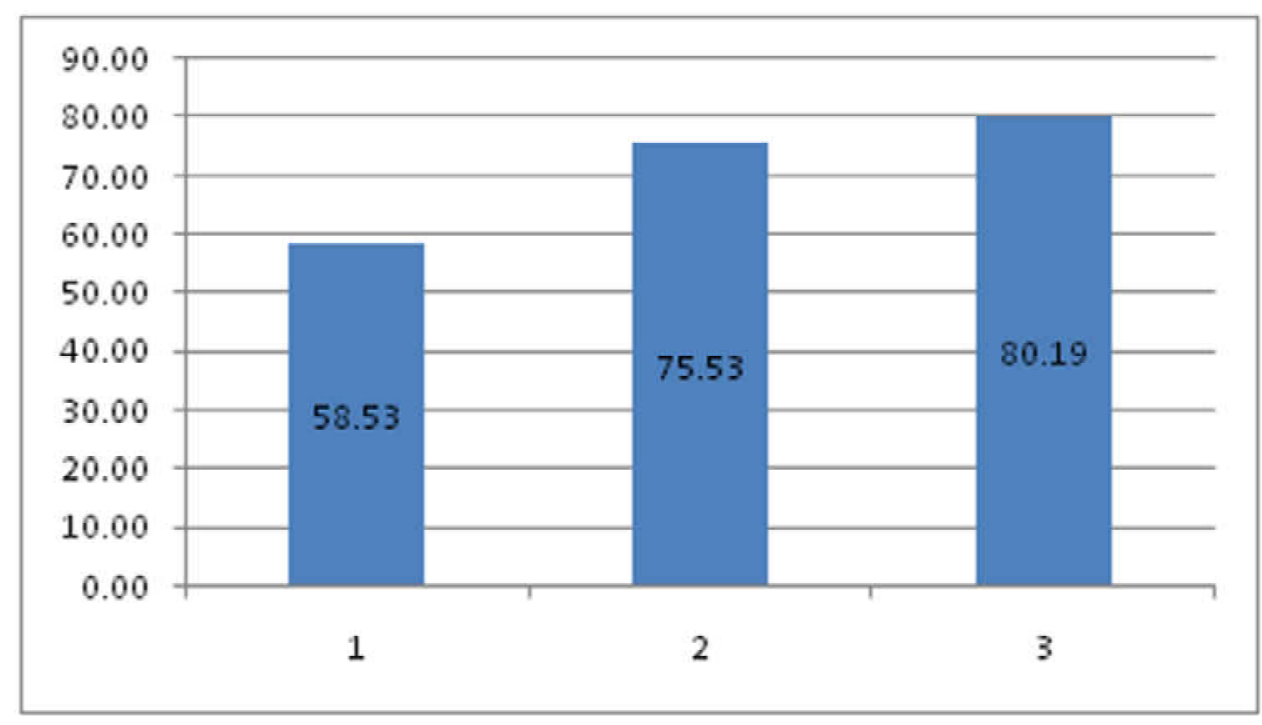

Diagram 3:

Kondisi Awal (1), Siklus 1 (2), Siklus 2 (3)

(Diolah oleh: Dinny Devi T)

Berikut ditunjukkan dalam bentuk diagram hasil mulai dari pra kondisi, siklus 1, dan siklus 2:

\section{SIMPULAN}

Berdasarkan hasil penelitian adanya peningkatan kemampuan menari peserta didik, di mana pada pra kondisi hanya memiliki nilai rata-rata 58,53, siklus 1 memiliki nilai rata-rata 75,53, dan siklus 2 memilik nilai rata-rata 80,19 . Prosentasi kenaikan dari pra kondisi ke siklus 1 sebesar $17 \%$, sedangkan dari siklus 2 sebesar 4,7\%, maka dapat disimpulkan:

1. Jika pada mata kuliah praktik tari memiliki masalah: a) rasio peserta didik dan pengajar yang tidak seimbang, b) keterbatasan skill pengajar mengingat kemampuan psikomotor mulai menurun, c) ruang kelas yang tidak sesuai dengan karakteristik mata kuliah dan pembelajaran, d) kemampuan peserta didik di bawah rata-rata dan terganggunya jumlah tatap muka yang seharusnya, dan e) penilaian kinerja yang digunakan dalam menilai praktik tari. Maka lakukan evaluasi formatif secara berkelanjutan yang dilakukan dengan bantuan media elektronik yang dimiliki peserta didik untuk merekam kemampuan menari yang dimiliki dan merefleksi secara bersama-sama, baik antara pengajar dan peserta didik maupun antarpeserta didik dari waktu ke waktu.

2. Tenaga pengajar harus menggunakan strategi penilaian yang terstruktur, dimulai dengan analisis kemampuan awal dengan pre test, dan evaluasi formatif secara sistematis dan berkelanjutan yang dievalusi dengan memberikan refleksi antara teman sejawat, dan tenaga pengajar. Strategi penilaian ini juga dapat membantu peserta didik dalam memahami kemampuan dirinya dan orang lain. Bersikap santun dan jujur dalam mengungkapkan pendapat ketika merefleksi diri atau menilai temannya. Selain itu dapat membantu pengajar dalam mengobservasi kemajuan keterampilan menari peserta didik 
secara berkelanjutan.

3. Evaluasi formatif yang dilakukan tenaga pengajar dapat mendiagnosis kemampuan peserta didik dengan cara yang praktis dan efesien, karena pada kegiatan ini akan terjadi refleksi dan penilaian secara berkelanjutan serta tidak menimbulkan tekanan psikologis seperti halnya apabila dilakukan tes keterampilan. Disamping itu hasil penilaian dapat meminimalisasi subjektivitas dalam menilai kemampuan menari peserta didik, sehingga nilai akhir mata kuliah praktik tari dapat dipertanggungjawabkan dengan baik, sehinggaakan berdampak pada IPK peserta didik.

Berdasarkan hasil penelitian tersebut, maka disarankan 1) Pada saat melaksanakan perkuliahan praktik tari, pengajar mempersiapkan dengan baik instrumen yang diberikan kepada peserta didik untuk merefleksi kemampuan menarinya, 2)Pengajar dan peserta didik memiliki tujuan yang sama, karena ketika melakukan refleksi dan penilaian akan terjadi kritik atau masukan baik dari peserta didik maupun dari pengajar secara terus menerus setiap kali tatap muka atau pembelajaran, 3) Pengajar dan peserta didik memiliki kemampuan dalam memanfaatkan teknologi yang baik, 4)Pengajar dan peserta didik memiliki sikap jujur dan santun pada saat merefleksi, karena terjadi diskusi yang sifatnya mengkritisi dan memberikan masukan.

\section{Daftar Pustaka}

Aiken, R Lewis

1988 Psychology Testing and Measurement. Boston: Allyn and Bacon, Inc.

Arikunto, Suharsimi

2006 Prosedur Penelitian Suatu Pendekatan Praktek Edisi Revisi IV . Jakarta: Rineka Cipta.
Cangelosi, James S

1995 Merancang Tes Untuk Menilai Prestasi Siswa (terj. Lilian D Tedjasudjana).Bandung : ITB.

Dantes, Nyoman

2009 Makalah: Hakikat Assessemen Otentik Sebagai Penilaian Proses dan Produk dalam Pembelajaran yang Berbasis Kompetensi, h. 3. (http:// profdantes.wordpress.com, diakses 20 Februari 2010).

Doubler, Margareth

1985 Tari Pengalaman Seni yang Kreatif, terjemahan T. Kumorohadi. Surabaya: Sekolah Tingi Kesenian Wilatikta.

Hawkins, Alma M

1990 Mencipta Lewat Tari, terjemahan Y. Sumandiyo Hadi. Yogyakarta: Institut Seni Indonesia.

Hutchinson, Ann

1989 Labanotation or Kinetography Laban: The System of Analyzing and Recording Movement. New York: Theatre Arts Books.

Humphrey, Doris

1964 The Art of Making Dances. New York: Holt, Rinehart, and Winstons.

Kemmis, Stephen and McTaggart

1999 The Action Research Planer. Australia: National Library of Australia.

Laban, Rudolf

1992 The Mastery of Movement. Playmouth: Northcote.

Langer K, Susan

1985 Problems of Art, terjemahan F.X. Widaryanto distensil oleh ASTI Bandung. New York: Charles Cribner's Sons.

Martin, John,

1989 The Modern Dance. New York: Princeton Book Company.

Mulyana, dkk

2004 Evaluasi Pendidikan. Jakarta: lembaga Akta Mengajar Universitas Negeri Jakarta.

Popham W, James

1995 Classroom Assessment What Teacher 
Need to Know. Boston: Allyn \& Bacon.

Slater, Wendy

1993 Dance and Movement in The Primary School. Playmouth: Northcote House.

Smith, Jacquline, terjemahan Ben Suharto 1985 Komposisi Tari: Sebuah Petunjuk Praktis Bagi Guru. Yogyakarta: Ikalasti.

Sudjana

1996 Metode Statistika. Bandung: Penerbit Tarsito.

Suryabrata, Sumadi

1988 Psikologi Pendidikan. Jakarta: Raja Grafindo Persada.
Thraves, Barbara and Diana Williamson

1993 Now for a Dance. Albert Part: Phoenix Education.

Triana D, Dinny

2012 Disertasi: Pengaruh Penilaian Kinerja dan Penguasaan Pengtahuan Komposisi Tari Terhadap Kecerdasan Kinestetik Peserta didik dalam Menata Tari (Eksperimen pada Peserta didik UNJ dan UPI Bandung).

Triana D, Dinny, Rahmida Setyawati

2014 Praktik Tari Betawi. Jakarta: Indraprasta Gemilang.

Winkel, WS

1997 Psikologi Pendidikan dan Evaluasi Belajar. Jakarta: Gramedia. 